\title{
Visual Thinking Routines: Classroom Snapshots
}

\author{
By Alain Gholam*
}

\begin{abstract}
Visual thinking routines are principles based on several theories, approaches, and strategies. Such routines, which are usually used again and again in the classroom, promote thinking skills, call for collaboration and sharing of ideas, and above all, make thinking and learning visible. Visual thinking routines are carried out in different Graduate Education courses at the American University in Dubai. The following article explores what visual thinking routines are, their merits, and how they are effectively implemented in the classroom. The visual thinking routines administered in the courses (I see, I think, I wonder routine; Connect, Extent, Challenge routine; 4C's routine; Headlines routine; Color, Symbol, Image routine; Sentence, Phrase, Word routine; and I used to think... Now I think... routine) are described in the article in reference to the following three components: 1) Thinking moves: What thinking moves does the described thinking routine reinforce? 2) Application: When and how can the described routine be used? and 3) Classroom Example: How is the described routine used in the Graduate Education courses at the American University in Dubai? The article also documents snapshots and actual examples from classroom practices at the Graduate School of Education at the American University in Dubai. As with all original, new, and unique resources, visual thinking routines are not free of challenges. To make the most of this useful and valued resource, educators need to comprehend, model, and spread awareness of the effective ways of implementing such routines in the classroom. It is crucial that such routines are meaningfully and effectively integrated into the curriculum to reinforce thinking skills, collaboration, creativity, and make learning visible.
\end{abstract}

Keywords: Visual Thinking Routines, Thinking Skills, 21st Century Education.

\section{Thinking: Identified and Explained}

Thinking is a major component in schools, as students are encouraged to think at all times and everywhere. Let us stop for a while and think about the various definitions of thinking. What is meant by the term, 'thinking'? What makes thinking so special and important? What are thinking skills? How can a teacher tell a child is thinking? Sousa (2011) believes that thinking is easier to describe than to define: "its characteristics include the daily routine of reasoning where one is at the moment, where one's destination is, and how to get there" (p. 250). Orlich, Harder, Callahan, Trevisan, and Brown (2012) mention that thinking is a multifaceted act that includes attitudes, knowledge, and skills, which allow an individual to effectively shape his or her environment. On the other hand, Arends (2014) explains that thinking is a mental process involving a variety of operations such as induction, deduction, classification, and reasoning. In conclusion:

\footnotetext{
*Assistant Professor, American University in Dubai, UAE.
} 
"Thinking skills are the mental processes we use to do things like solve problems, make decisions, ask questions, make plans, pass judgments, organize information, and create new ideas. Often we're not aware of our thinking - it just happens automatically." (Moore, 2015, p.376)

The various definitions suggest that thinking is purposeful and involves a certain cognitive process. It is important to also consider some other essential and vital questions related to thinking: What types of thinking do teachers value in their classroom? Do teachers want their students to understand? analyze? interpret? reason? What types of thinking do specific disciplines, assignments, and activities call for? Ritchhart, Church, and Morrison (2011) clarify the types of thinking that are essential and central to different subject areas:

"We need to be aware of the kinds of thinking that are important for scientists (making and testing hypotheses, observing closely, building explanation....), mathematicians (looking for patterns, making conjectures, forming generalizations, constructing arguments....), readers (making interpretations, connections, predictions....), historians (considering different perspectives, reasoning with evidence, building expectations....), and so on, and make these kinds of thinking the center of the opportunities we create for students." (p. 10-11)

What about interdisciplinary thinking? Ritchhart Church, and Morrison (2011) include important questions related to interdisciplinary connections: "Are there particular kinds of thinking that serve understanding across all disciplines? Types of thinking that are particularly useful when we are trying to understand new concepts, ideas, or events?" (p.11). The authors suggest eight thinking activities that are integral to understanding: 1) observing closely and describing what's there, 2) building explanations and interpretations, 3) reasoning with evidence, 4) making connections, 5) considering different viewpoints and perspectives, 6) capturing the heart and forming conclusions, 7) wondering and asking questions, and 8) uncovering complexity and going below the surface of things (p.11-18).

The eight thinking moves are logical. Let us connect this valuable information to our own experiences. We do use such thinking moves to reach understanding - an understanding of an idea, thought, or any new novel situation. We may first observe closely and try to describe what we see and what we think. We try to make sense of what we experience. Then, we may find ourselves engaged in different explanations and interpretations that are built on evidence. We may even make connections with our previous knowledge of a certain idea, thought, or situation. Finally, we may be involved in different conversations and talks to consider different perspectives, raise questions and doubts, and reach final conclusions. Such processes become valued and visible in the classroom when they start being reinforced and modeled by the teacher. When students become familiarized with the various thinking moves, they refer to them to identify what they will be doing to learn. As a result, students 
become more aware of their own thinking strategies and processes, and this in turn leads to metacognition (Ritchhart, Tuner, \& Hadar, 2009). Metacognition, which is the ability to form a judgment related to our own thoughts, is a precursor for learning and success (Fleming, 2014).

Let us consider the question posted at the beginning of the article: What types of thinking do teachers want to value in their own classrooms? Teachers definitely want their students to understand, but, is the only goal of thinking to reach understanding? We also think to go beyond the facts and make connections, solve problems, make judgements, and reach generalizations. Ritchhart Church and Morrison (2011) suggest additional types of thinking moves that need to be valued in the classroom: 1) identifying patterns and making generalizations, 2) generating possibilities and alternatives, 3) evaluating evidence, arguments, and actions, 4) formulating plans and monitoring actions, 5) identifying claims, assumptions, and bias, and 6) clarifying priorities, conditions, and what is known.

\section{Visual Thinking Routines: What? Why? How?}

We should also note that thinking is usually invisible. So, if thinking is invisible, what is really meant by the term, visible thinking? Tishman and Palmer (2005) refer to visible thinking as any kind of observable representation that documents the development of an individual's or group's thinking, questions, and reflections. They argue that tools such as mind maps, charts and lists, diagrams, and worksheets are considered visible thinking if and only if they make students' thinking visible. Ritchhart and Perkins (2008) provide a list of characteristics that anchor visible thinking. Some of these characteristics include: learning happens as a result of thinking; the development of thinking is a social endeavor; and developing thinking requires making thinking visible. Visual thinking is a flexible framework that encompasses a variety of methods to make students' thinking visible to themselves, their peers, and teachers (Dajani, 2016).

What tools are used to make thinking visible? Questions promote visible thinking. Teachers ask their students questions on a daily basis, however, it is important to note that the purpose and form of these questions can vary widely (McTighe \& Wiggins, 2013). Tishman (2002) provides an example by stating that questions, such as "What is going on here?" "What do you see that makes you say so?" call for visible thinking. Johnston, Ivey, \& Faulkner (2011) affirm that such questions convey that you are expecting your students to engage in thinking and you are interested in their response. Ritchhart, Church, and Morrison (2011) clarify that: "Open-ended questions - as opposed to closedended, single-answer questions - are generally advocated as means of pushing beyond knowledge and skill and toward understanding" (p.30). Ritchhart (2012) believes that teachers need to understand how the use of questioning can help foster a culture of thinking and make a classroom a place where individual and collaborative thinking is valued, visible, and actively promoted.

Listening is another tool that is used to make thinking visible. Listening 
conveys a sense of respect for and an interest in the learner's contributions, and when this is present, students are more willing to share their thinking and put forth their ideas (Ritchhart, Church, \& Morrison, 2011). Sue Patton Thoele has highlighted the role of listening in the classroom: "Deep listening is miraculous for both listener and speaker. When someone receives us with open-hearted, non-judging, intensely interested listening, our spirits expand" (quoted in Rao, 2010, p.24).

Other tools that can be used to make student thinking visible are visual thinking routines. Such tools are referred to as routines because they represent a sequence of actions designed to achieve a specific outcome in an efficient manner (Ritchhart, 2015). Visual thinking routines were first designed by Faculty at the Harvard Graduate School of Education:

"Thinking routines are one element of an initiative called Visible Thinking that we, our colleagues at Project Zero, and collaborators in various schools have developed. In our research, we have explored the practically of using thinking routines and documentation as classroom learning tools, developed a framework for pursuing cultural transformation in classroom and schools, and devised tools for integrating the arts. This work has spanned elementary through university settings, included both public and independent schools, and involved schools in the United States, the Netherlands, Sweden, Belgium, and Australia" (Ritchhart \& Perkins, 2008, p.57)

Wolberg and Goff (2012) provide a rationale for implementing thinking routines in the classroom and explain that such routines make students' thinking and learning visible to themselves, peers, and teachers. Costa (2008) strongly believes that thinking needs practice and students need practice, reflection, and modeling to engage in skillful thinking. Researchers highlight that visual thinking helps learners connect with familiar and relevant events in their lives, expands their repertoire of thinking, engages them in the learning process, and motivates them to learn (Salmon, 2010; Ritchhart, Church, \& Morrison, 2011). Visual thinking promotes deep inquiry (Project Zero, 2010). Tishman and Palmer (2006) also assert that visual thinking reinforces skills through engagement and participation and deepens students' understanding. Wolberg and Goff (2012) stress the fact that "certain thinking skills, such as being able to understand different points of view or providing evidence, do not come naturally to young children and must be taught explicitly and strengthened within a learning environment" (p.60). When students recognize relationships between facts and questions and claims and evidence, they form authentic knowledge (Ritchhart, Palmer, Church, \& Tishman, 2006). Dajani (2016) mentions that visual thinking creates a learning environment where students are: open-minded, curious, critical, and skeptical. In addition, Dajani (2016) explicates that visual thinking allows teachers to track difficulties and challenges students come across. According to Ritchhart (2015), visual thinking forms a culture of thinking where students are strongly encouraged to make great use of quality thinking time, share collaboratively, and reflect upon the different viewpoints and perspectives of 
their peers. Ritchhart (2004) confirms that in such creative classrooms students are doing more than just learning content, and teachers are doing more than teaching. Hattie (2012) notes that since visual thinking makes learning visible, teachers can know whether they have an impact on learning, and since it makes teaching visible, students can learn how to engage in metacognition and thus become their own teachers. Ritchhart (2007) strongly believes that a quality curriculum engages students in a variety of thinking moves, such as, making connections, observing closely, asking questions, and evaluating outcomes.

In the classroom, visual thinking routines are used in three different ways. First, they can be used as tools to support specific thinking moves such as: making connections, describing what is present, building explanations, considering different viewpoints and perspectives, capturing the heart and forming conclusion, and reasoning with evidence (Ritchhart, Church, \& Morrison, 2011). They are similar to cognitive strategies (Ritchhart, 2015). Barahal (2008) states that such routines are flexible and "can easily be used to strengthen student thinking about virtually any topic or subject, from a math problem to an historical document, from a poem to a work of art" (p.299). Salmon (2008) mentions that thinking routines provide students with meaningful and rich experiences in an arranged manner that offers overall structures in which learning takes place. Second, visual thinking routines can be used as structures where they follow a natural progression in which each step builds on and extends the thinking of the previous one: "Therefore, in using the routines the goal is never simply to fill out or complete one step and move on to the next but to use the thinking occurring at each step in the subsequent steps" (Ritchhart, Church, \& Morrison, 2011, p.47). Therefore, they become the scaffolds for thinking (Ritchhart, 2015). Wolberg and Goff (2012) proclaim that what makes thinking routines structures is the fact that they comprise a series of steps that provide teachers with a protocol for enabling thoughtful discussion in the classroom. Finally, visual thinking routines are used in the classroom as patterns of behavior (Ritchhart, Church, \& Morrison, 2011). Barahal (2008) clarifies that: "when used regularly, thinking routines help students master and internalize new thinking processes until they become second nature" (p.299). They are used regularly and become part of the pattern of the classroom, and students internalize messages about what learning is and how it happens (Ritchhart, Church, \& Morrison, 2011). Therefore, after several uses in the classroom, teachers can initiate any thinking routine merely by naming it (Ritchhart, Palmer, Church, \& Tishman, 2006).

Visual thinking routines are designed in such a manner to serve different purposes in the classroom: routines for introducing and exploring ideas, routines for synthesizing and organizing ideas, and routines for digging deeper into ideas (Ritchhart, Church, \& Morrison, 2011). Table 1 shows a brief overview of visual thinking routines used for introducing and exploring ideas. 
Table 1. Routines for Introducing and Exploring Ideas

\begin{tabular}{|l|l|}
\hline Routine & Key Thinking Moves \\
\hline \multicolumn{2}{|c|}{ Routines for Introducing and Exploring Ideas } \\
\hline See-Think-Wonder & Describing, interpreting, and wondering \\
\hline Zoom In & Describing, inferring, and interpreting \\
\hline Think-Puzzle-Explore & Activating prior knowledge, wondering, planning \\
\hline Chalk Talk & Uncovering prior knowledge and ideas, questioning \\
\hline 3-2-1 Bridge & $\begin{array}{l}\text { Activating prior knowledge, questioning, distilling, and } \\
\text { connection making through metaphors }\end{array}$ \\
\hline Compass Points & $\begin{array}{l}\text { Decision making and planning, uncovering personal } \\
\text { reactions }\end{array}$ \\
\hline The Explanation Game & Observing details and building explanations \\
\hline
\end{tabular}

Source: Ritchhart, Church, \& Morrison, 2011, p.51.

Table 2 shows a brief overview of visual thinking routines used for synthesizing and organizing ideas.

Table 2. Routines for Synthesizing and Organizing Ideas

\begin{tabular}{|c|c|}
\hline Routine & Key Thinking Moves \\
\hline \multicolumn{2}{|c|}{ Routines for Synthesizing and Organizing Ideas } \\
\hline Headlines & Summarizing, capturing the heart \\
\hline Color, Symbol, Image & Capturing the heart through metaphors \\
\hline $\begin{array}{l}\text { Generate-Sort-Connect- } \\
\text { Elaborate: Concept Maps }\end{array}$ & $\begin{array}{l}\text { Uncovering and organizing prior knowledge to identify } \\
\text { connections }\end{array}$ \\
\hline Connect-Extend-Challenge & $\begin{array}{l}\text { Connection making, identifying new ideas, raising } \\
\text { questions }\end{array}$ \\
\hline The 4C's & $\begin{array}{l}\text { Connection making, identifying key concept, raising } \\
\text { questions, and considering implications }\end{array}$ \\
\hline The Micro Lab Protocol & Focusing attention, analyzing, and reflecting \\
\hline $\begin{array}{l}\text { I Used to Think... Now I } \\
\text { Think }\end{array}$ & Reflecting and metacognition \\
\hline
\end{tabular}

Source: Ritchhart, Church, \& Morrison, p.51-52.

Table 3 shows a brief overview of visual thinking routines for digging deeper into ideas.

Table 3. Routines for Digging Deeper into Ideas

\begin{tabular}{|l|l|}
\hline Routine & Key Thinking Moves \\
\hline Routines for Digging Deeper into Ideas \\
\hline What Makes you say That? & Reasoning with evidence \\
\hline Circle of Viewpoints & Perspective taking \\
\hline Step Inside & Perspective taking \\
\hline Red Light, Yellow Light & Monitoring, identifying of bias, raising questions \\
\hline Claim, Support, Question & $\begin{array}{l}\text { Identifying generalizations and theories, reasoning with } \\
\text { evidence, making counterarguments }\end{array}$ \\
\hline Tug of War & Perspective taking, reasoning, identifying complexities \\
\hline Sentence-Phrase-Word & Summarizing and distilling \\
\hline
\end{tabular}




\section{Visual Thinking Routines: Pictures from Practice}

Visual thinking routines were carried out in different Graduate Education courses taught at the American University in Dubai during Fall 2016: EDCO602 Curriculum, Instruction, and Assessment, EDEL606 - Elementary Science and Mathematics Methods, and EDSE608 - Secondary Math Methods and Assessment. The participants referred to in the following paper were 17 student teachers enrolled in the three courses: EDCO602, EDEL606, and EDSE608. Nine student teachers were enrolled in EDCO602 (1 male and 8 females). One student teacher was teaching at the preschool level, two at the elementary level, one at the high/secondary level, and five were not teaching at the time. Five student teachers were enrolled in EDEL606 (1 male, 4 females). One student teacher was teaching at the preschool level, one at the elementary level, and three were not teaching at the time. Three student teachers were enrolled in EDSE608 (1 male and 2 females). Two student teachers were teaching at the high/ secondary level and 1 was not teaching at the time. A profile of the student teachers is presented in Table 4.

Table 4. Student Teacher Profiles

\begin{tabular}{|c|c|c|c|c|}
\hline Characteristics & EDCO602 & EDEL606 & EDSE608 & TOTAL \\
\hline Course Size & 9 & 5 & 3 & 17 \\
\hline Gender & 1 & 1 & 1 & 3 \\
\hline Male & 8 & 4 & 2 & 14 \\
\hline Female & \multicolumn{5}{|l|}{} \\
\hline Teaching Level & \multicolumn{5}{|l|}{} \\
\hline Preschool & 1 & 1 & 0 & 2 \\
\hline Elementary & 2 & 1 & 0 & 3 \\
\hline Middle & 0 & 0 & 0 & 0 \\
\hline High/Secondary & 1 & 0 & 2 & 3 \\
\hline Not teaching & 5 & 3 & 1 & 9 \\
\hline
\end{tabular}

I focused on modeling the utility of visual thinking routines in my courses for two main purposes: first, to ensure a student-centered learning culture that embraced the following essential factors: collaboration, reflection, and higherorder thinking; and second, to make sure student teachers receive hands-on experience related to visual thinking routines and implement them meaningfully in their own classroom.

In every learning session, student teachers enrolled in the courses were asked to make their thinking visible through a variety of visual thinking routines. The different routines were used as tools to promote engagement and deep understanding. They were seen and perceived as structures that followed predetermined steps and tasks designed by the professor. Therefore, with time such routines became patterns of behavior.

The thinking routines administered in the courses are described in the article hereby in reference to the following three components: Thinking moves: What thinking moves does the described thinking routine reinforce? Application: When and how can the described routine be used? Classroom Example: How 
was the described routine used in the Graduate Education courses at the American University in Dubai?

\section{Visual Thinking Routine 1: I see, I think, I wonder}

Instructions: According to Ritchhart, Church, and Morrison (2011), I see, I think, I wonder routine includes the following directions or order:

\section{Looking at an image or object: \\ What do you see? \\ What do you think? \\ What do you notice? (p. 55)}

Thinking moves: The "I see, I think, I wonder" routine is used for description, interpretation, and wondering purposes. Such a routine highlights the essence of observation, as it first requires students to carefully look at an image or object. Then, it involves them in thinking and interpretation, as students are expected to make meaning from their observations. Finally, students are asked to formulate meaningful questions and wonderings related to the image or object they examine.

Application: I see, I think, I wonder routine can be used at the beginning of a lesson, when a teacher is about to introduce a new concept, making it a perfect tool for exploration. I see, I think, I wonder routine can even be administered as an exist card at the closure of a lesson. Students can also watch short movies or even observe their surrounding and engage in the routine. In summary, it can be a valuable and a meaningful tool anytime during the lesson. Students can be given the choice to work individually, in pairs, or in groups. For assessment purposes, I see, I think, I wonder routine can be used as a pre-assessment, formative assessment, and even as a summative assessment. Table 12 represents a summary of the routine's thinking moves and application.

Classroom Example: Throughout two learning sessions, student teachers were inquiring into the purpose, focus, and uses of assessment and evaluation. At the beginning of the second session, they were asked to carefully observe a picture of a chef trying to blend different ingredients together and tasting the dish before being served. Student teachers were asked to report what they observed, thought, and wondered about the picture. They were strongly encouraged to see the connection between the image and the concept under exploration, assessment. A whole classroom discussion followed. Table 5 represents a descriptive summary of the student teachers' responses. 
Table 5. Student Teachers' Responses - I See, I Think, I Wonder

\begin{tabular}{|c|c|c|}
\hline I See & I Think & I Wonder \\
\hline $\begin{array}{c}\text { A woman, white blowse } \\
\text { cooking tools }\end{array}$ & $\begin{array}{l}\text { She is tasting her food in } \\
\text { order to see if she is } \\
\text { satisfied with results }\end{array}$ & $\begin{array}{l}\text { I wonder if she is satisfied } \\
\text { with the results }\end{array}$ \\
\hline Someone preparing food & $\begin{array}{c}\text { She is a cook, assessing } \\
\text { the food }\end{array}$ & $\begin{array}{l}\text { What stage is she } \\
\text { assessing in }\end{array}$ \\
\hline A lady tasting food! & $\begin{array}{c}\text { She looks like she's } \\
\text { experimenting }\end{array}$ & $\begin{array}{l}\text { What is she thinking: } \\
\text { assessing or evaluating? }\end{array}$ \\
\hline $\begin{array}{l}\text { Observing, checking what } \\
\text { she has }\end{array}$ & $\begin{array}{l}\text { She is assessing a } \\
\text { student's work }\end{array}$ & $\begin{array}{l}\text { If she thinks student has } \\
\text { done well? }\end{array}$ \\
\hline A lady & $\begin{array}{l}\text { The lady is a chef and she } \\
\text { is tasting something she } \\
\text { made }\end{array}$ & $\begin{array}{l}\text { What she is tasting? Why } \\
\text { is she alone? }\end{array}$ \\
\hline A sink & $\begin{array}{l}\text { I think someone who did } \\
\text { a big effort in cooking } \\
\text { and now she is tasting her } \\
\text { food }\end{array}$ & $\begin{array}{l}\text { I wonder if she spotted } \\
\text { something strange? }\end{array}$ \\
\hline Kitchen utensils & $\begin{array}{l}\text { I think she is trying to } \\
\text { check if the blended } \\
\text { ingredients up to the level } \\
\text { she wants! }\end{array}$ & $\begin{array}{l}\text { I wonder if she will fix } \\
\text { and add more amount of } \\
\text { the ingredients! }\end{array}$ \\
\hline Kitchen appliances & $\begin{array}{l}\text { I think she has to use her } \\
\text { expertise to judge what } \\
\text { she has just tasted }\end{array}$ & $\begin{array}{l}\text { I wonder if she will } \\
\text { condemn the novice for } \\
\text { his/her messiness of base } \\
\text { judgement only on } \\
\text { product }\end{array}$ \\
\hline $\begin{array}{l}\text { A chef making } \\
\text { something, looks like } \\
\text { dessert to me, she is } \\
\text { observing the spoon }\end{array}$ & $\begin{array}{l}\text { I think she might have } \\
\text { spotted something while } \\
\text { mixing. She might be } \\
\text { checking an amount of } \\
\text { what she wants to add }\end{array}$ & $\begin{array}{l}\text { I wonder what is she } \\
\text { cooking }\end{array}$ \\
\hline \multicolumn{3}{|l|}{ I see a woman cooking } \\
\hline \multicolumn{3}{|l|}{$\begin{array}{l}\text { A woman trying to blend } \\
\text { some ingredients }\end{array}$} \\
\hline $\begin{array}{l}\text { I see a chef (based on } \\
\text { attire) in a novice's } \\
\text { kitchen }\end{array}$ & & \\
\hline
\end{tabular}

Figure 1 shows a visual representation of the student teachers' responses. 
Figure 1. Visual Representation - I See, I Think, I Wonder

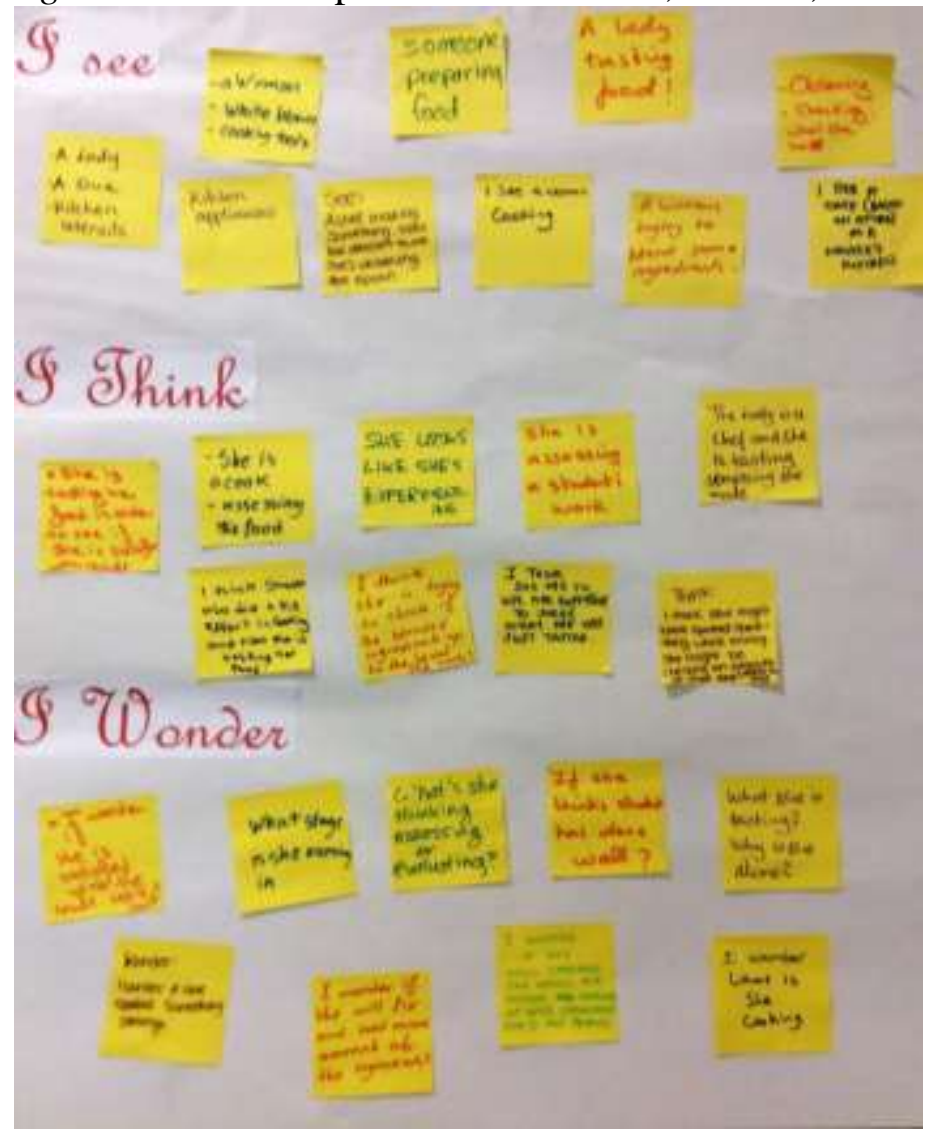

\section{Visual Thinking Routine 2: Connect, Extend, Challenge}

Instructions: According to Ritchhart, Church, and Morrison (2011), the "Connect, Extend, Challenge" routine includes the following directions or order:

Consider what you have just read, seen, or head, then ask yourself:

1. How are the ideas and information presented connected to what you already knew?

2. What new ideas did you get that extended or broadened your thinking in new directions?

3. What challenges or puzzles have come up in your mind from the ideas and information presented? (p.132)

Thinking moves: The Connect, Extend, Challenge routine helps students bring together and assemble different pieces of information. It can be used as a reflection tool to assist students in making connections with what they already know, identifying new ideas that push their thinking deeper, and raising questions for further examination and analysis. It offers rich opportunities for newly acquired thinking to form from a variety of learning experiences 
Table 6. Student teachers' responses - Connect, Extend, Challenge

\begin{tabular}{|c|c|c|}
\hline \multirow{2}{*}{ Connect } & \multirow{2}{*}{\multicolumn{2}{|c|}{ Extend }} \\
\hline & & \\
\hline Ships from tell to do & $\begin{array}{c}\text { Students should think, } \\
\text { analyze, create, and explore }\end{array}$ & $\begin{array}{c}\text { What about the number of } \\
\text { students in class? }\end{array}$ \\
\hline Inquiry based = questions & Prescriptive, guided, open & $\begin{array}{c}\text { Testing, Differentiation vs } \\
\text { std. testing }\end{array}$ \\
\hline $\begin{array}{c}\text { Theory }+ \text { practice }=\text { Best } \\
\text { teaching methods }\end{array}$ & $\begin{array}{l}\text { In Maths: focuses not on } \\
\text { calculation but application }\end{array}$ & $\begin{array}{l}\text { How to engage all children } \\
\text { in critical thinking }\end{array}$ \\
\hline $\begin{array}{l}\text { It confirmed my } \\
\text { understanding of IBL }\end{array}$ & $\begin{array}{l}\text { Shift from simple coverage } \\
\text { to a deep understanding }\end{array}$ & $\begin{array}{l}\text { Inquiry based in little } \\
\text { children???? }\end{array}$ \\
\hline $\begin{array}{l}21^{\text {st }} \text { Century learner } \\
\text { requirement: think, } \\
\text { communicate, collaborate } \\
\end{array}$ & $\begin{array}{l}\text { Preparation for the future } \\
\text { and work challenges }\end{array}$ & $\begin{array}{l}\text { Reaching the brains of } \\
\text { challenging students }\end{array}$ \\
\hline $\begin{array}{l}\text { Covering to uncovering } \\
\text { the curriculum, deeper } \\
\text { understanding, real world } \\
\text { experience }\end{array}$ & $\begin{array}{l}\text { Developing thinking and } \\
\text { not memorization }\end{array}$ & $\begin{array}{l}\text { Teachers need a lot of } \\
\text { training }\end{array}$ \\
\hline $\begin{array}{c}\text { Generalizations to apply } \\
\text { what we learn to real life } \\
\text { situations, schools need to } \\
\text { better represent the real } \\
\text { world }\end{array}$ & $\begin{array}{c}\text { Problem solvers succeed in } \\
\text { the future }\end{array}$ & $\begin{array}{l}\text { I didn't feel any general } \\
\text { educator can teach easily } \\
\text { using IBL }\end{array}$ \\
\hline Active participants & $\begin{array}{l}21^{\text {st }} \text { Century skills: critical } \\
\text { skills, communication, } \\
\text { collaboration }\end{array}$ & $\begin{array}{c}\text { Practical side? How does it } \\
\text { work? }\end{array}$ \\
\hline \multirow[t]{6}{*}{$\begin{array}{l}\text { Asking questions, gather } \\
\text { data, think and decide }\end{array}$} & $\begin{array}{c}21^{\text {st }} \text { Century skills: critical } \\
\text { skills, communication, } \\
\text { collaboration }\end{array}$ & $\begin{array}{l}\text { Is it the only magical } \\
\text { solution? }\end{array}$ \\
\hline & $\begin{array}{c}\text { In Math you can use } \\
\text { inquiry }\end{array}$ & $\begin{array}{l}\text { How do you test analytical } \\
\text { higher order thinking? }\end{array}$ \\
\hline & $\begin{array}{l}\text { Inquiry trains the brain to } \\
\text { find solutions }\end{array}$ & $\begin{array}{l}\text { If the student didn't do } \\
\text { good or learn well from } \\
\text { the inquiry what is to be } \\
\text { done to help him? }\end{array}$ \\
\hline & $\begin{array}{c}\text { Knowledge, no need to } \\
\text { memorize: not final goal as } \\
\text { before }\end{array}$ & \\
\hline & $\begin{array}{l}\text { Cognitive science }+ \text { educ. } \\
\text { psychology helps increase } \\
\text { teacher effectiveness }\end{array}$ & \\
\hline & $\begin{array}{c}\text { Real world experience }= \\
\text { engagement }\end{array}$ & \\
\hline
\end{tabular}

Application: Connect, Extend, Challenge routine can be used when a teacher is about to launch a new inquiry or after students acquire new information. It can even be used as a closure engagement, as teachers may ask their students to make use of such a routine and engage in self-reflection. Students can be given the choice to work individually, in pairs, or in groups. For assessment purposes, 
Connect, Extend, and Challenge routine can be used as a pre-assessment, formative assessment, and even as a summative assessment. Table 12 represents a summary of the routine's thinking moves and application.

Classroom Example: Student teachers were investigating the characteristics, examples, and non-examples of inquiry based learning. They were asked to read and explore a document related to inquiry-based learning. Then, student teachers were requested to pair up and share their thoughts, wonderings, and views on the reading. As an exist ticket, student teachers had to individually complete a Connect, Extend, and Challenge routine. A whole classroom discussion followed. Table 6 represents a descriptive summary of the student teachers' responses.

Figure 2 shows a visual representation of the student teachers' responses.

Figure 2. Visual Representation - Connect, Extend, Challenge

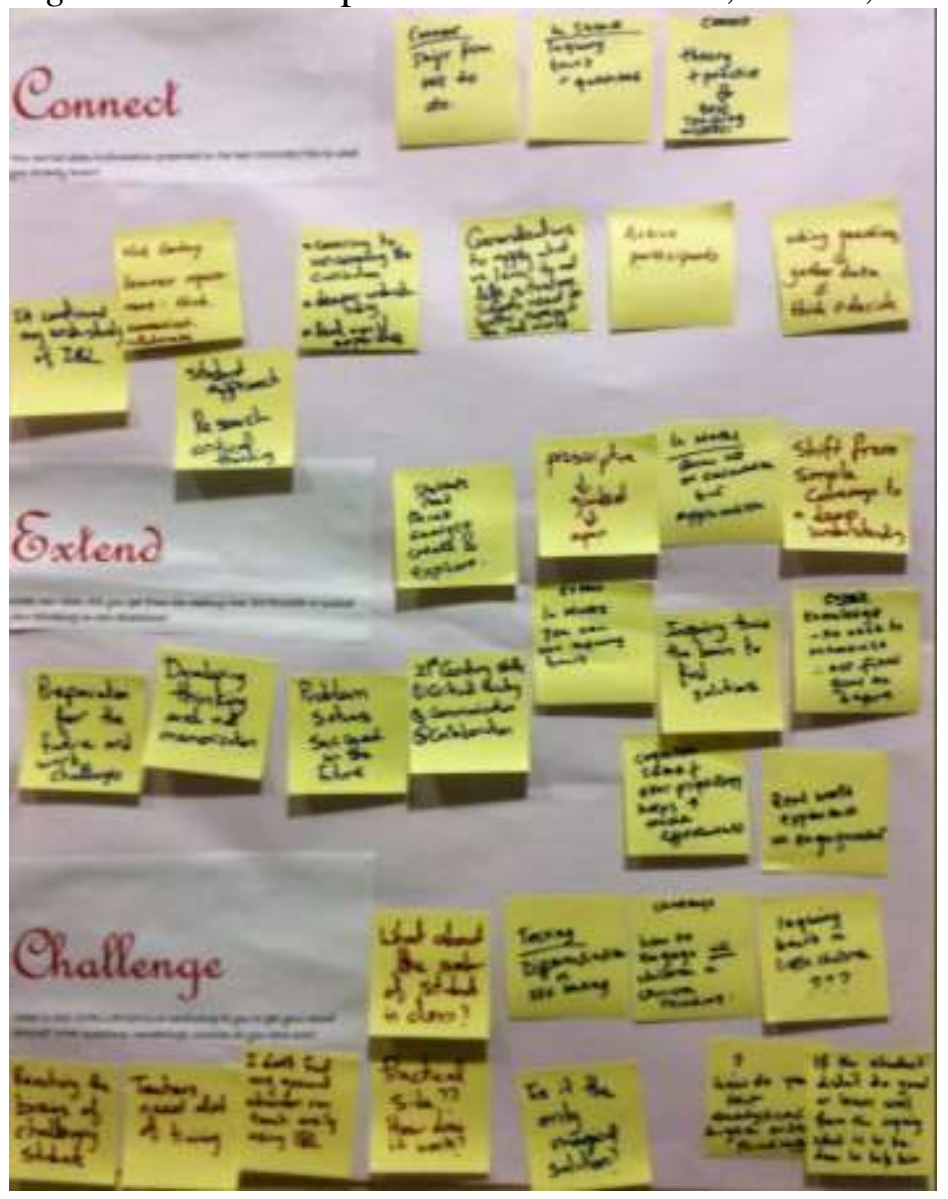

Visual Thinking Routine 3: The 4C's

Instructions: According to Ritchhart, Church, and Morrison (2011), The 4C's routine includes the following directions or order: 
1. Connections: What connections do you draw between the text and your own life or your other learning?

2. Challenge: What ideas, positions, or assumptions do you want to challenge or argue with in the text?

3. Concepts: What key concepts or ideas do you think are important and worth holding on to from the text?

4. Changes: What changes in attitudes, thinking, or action are suggested by the text, either for you or others? (p.140)

Thinking moves: The 4C's routine reinforces and strengthens text built discussions by asking the students to make connections, challenge ideas or assumptions, ask questions, identify important relevant concepts, and consider change. It is a meaningful and engaging routine that promotes text-to-self connections, critical and analytical thinking, concept/theme identification, and synthesis.

Application: The 4C's routine can be used after reading a piece of literature. It can also take the form of an exist ticket. Teachers who implement such a visual thinking routine involve their students in deep self-reflection by challenging them to think how the lesson is connected to what they already know, what ideas do they find difficult or wish to test, compare the different ideas to unwrap hidden messages, and identify any possible change in thought or behavior. Students can be given the choice to work individually, in pairs, or in groups. For assessment purposes, 4C's routine can be used as a pre-assessment, formative assessment, and even as a summative assessment. Table 12 represents a summary of the routine's thinking moves and application.

Table 7. Student teachers' responses $-4 \mathrm{C}$ 's

\begin{tabular}{|c|c|c|c|}
\hline Connections & Challenges & Concepts & Changes \\
\hline $\begin{array}{c}\text { Area and side of } \\
\text { squares connected } \\
\text { to perfect squares } \\
\text { and square roots }\end{array}$ & $\begin{array}{c}\text { Multiplication } \\
\text { tables }\end{array}$ & Perfect squares & $\begin{array}{c}\text { Manipulatives } \\
\text { provide deep } \\
\text { understanding } \\
\text { showing the why } \\
\text { and how }\end{array}$ \\
\hline $\begin{array}{c}\text { Concrete materials } \\
\text { help the students } \\
\text { get their hands } \\
\text { involved as well as } \\
\text { their minds }\end{array}$ & $\begin{array}{c}\text { Asking } \\
\text { manipulatives area } \\
\text { of big \#'s }\end{array}$ & Square roots & $\begin{array}{c}\text { Better } \\
\text { understanding } \\
\text { about the square } \\
\text { unit }\end{array}$ \\
\hline & $\begin{array}{c}\text { Some students } \\
\text { don'tprefer to use it }\end{array}$ & Side measuring & $\begin{array}{c}\text { Will use } \\
\text { manipulatives in } \\
\text { the next square root } \\
\text { lesson }\end{array}$ \\
\hline & & Area & \\
\hline & & $\begin{array}{c}\text { Manipulatives: } \\
\text { hands-on experience }\end{array}$ & \\
\hline
\end{tabular}


Classroom Example: Student teachers were exploring the role of manipulatives in Mathematics. They were asked to read a document related to the use of manipulatives. In groups, they had to make connections with the text, identify any idea they wanted to challenge or found difficult, unwrap the concepts/ themes from the reading, and pinpoint any changes in attitudes or thinking. A whole classroom discussion followed. Table 7 represents a descriptive summary of the student teachers' responses

Figure 3 shows a visual representation of the student teachers' responses.

Figure 3. Visual Representation - 4C's

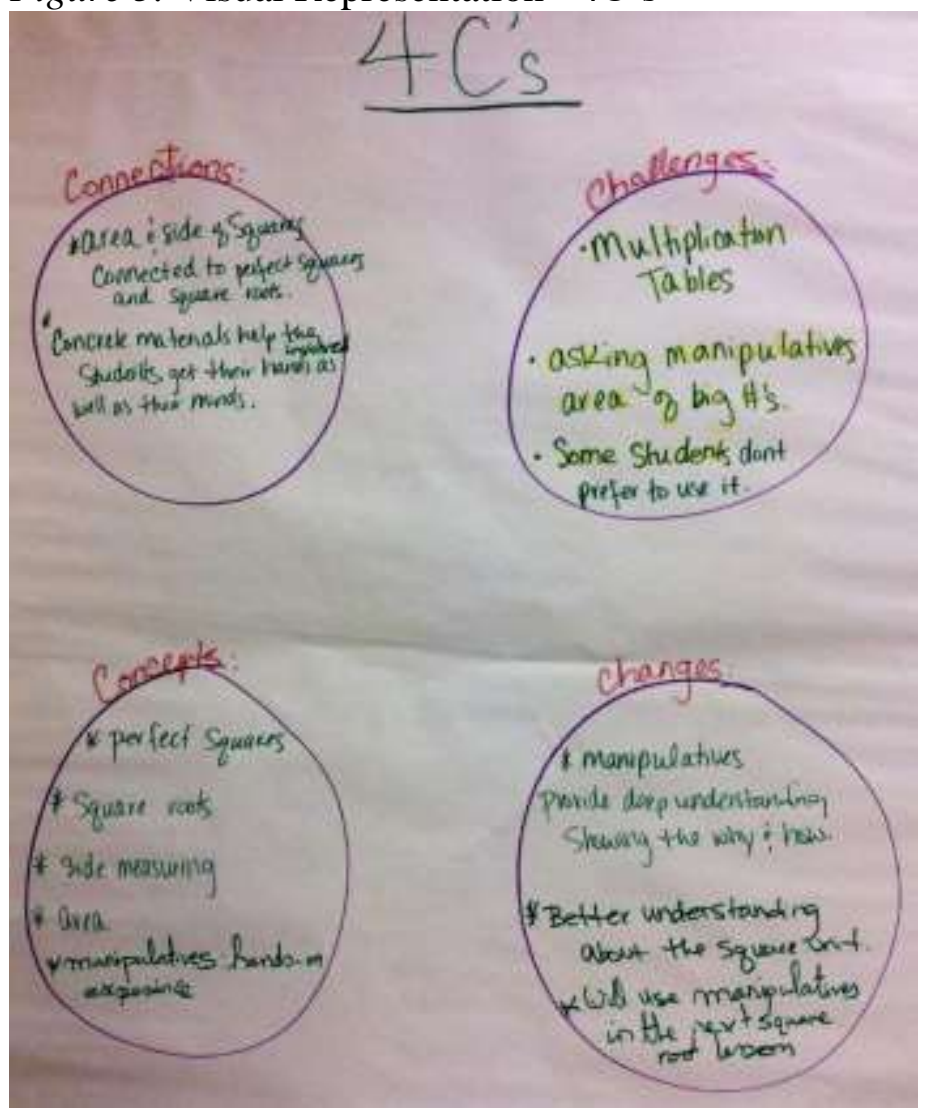

Visual Thinking Routine 4: Headlines

Instructions: According to Ritchhart, Church, and Morrison (2011), Headlines routine includes the following directions or order:

Think of the big ideas and important themes in what you have been learning. Write a headline for this topic or issue that summarizes and captures a key aspect that you feel is significant and important. (p.111)

Thinking moves: Headlines are used to provide a summary of a certain topic, issue, idea, or thought. They engage the students in apprehending and capturing the implications or core of the topic, issue, idea, or thought being explored. 
Application: Headlines can be used at the end of a lesson when a teacher expects the students to provide a brief summary or quick synthesis regarding a certain topic. They can also be used at the beginning of a lesson, by asking the students to design a headline that demonstrates what they already know about a certain issue, concept, idea, or topic. For assessment purposes, headlines routine can be used as a pre-assessment and formative assessment. Table 12 represents a summary of the routine's thinking moves and application.

Classroom Example: After spending some time inquiring into the essentials of project-based learning, student teachers were asked to write a headline that summed up their understanding of project-based learning and its impact on student learning. Student teachers were asked to present their headline to their colleagues. Table 8 represents a descriptive summary of the student teachers' responses.

Table 8. Student Teachers' Responses - Headlines

\begin{tabular}{|l|}
\hline \multicolumn{1}{|c|}{ Headlines } \\
\hline $\begin{array}{l}\text { Project Based Learning: communicate, collaborate, creative learning worldly, the } \\
\text { creative collaborative educational model }\end{array}$ \\
\hline Project Based Learning: The key to college and career ready students! \\
\hline Project Based Learning is a cycle of teaching methodology that promotes authentic, \\
$21^{\text {st }}$ century skills, analytical and inquiry skills in students. \\
\hline $\begin{array}{l}\text { PjBL promotes developing } 21^{\text {st }} \mathrm{C} \text { skills and develop transformation of knowledge to } \\
\text { real life. }\end{array}$ \\
\hline $\begin{array}{l}\text { Project Based Learning is a scientific process of learning starting with a question, } \\
\text { incorporating critical thinking and communication resulting in an end product } \\
\text { answering the question. }\end{array}$ \\
\hline $\begin{array}{l}\text { PjBL involves students in group work, exploration and creation to prepare them for } \\
21^{\text {st }} \text { century capable citizen. }\end{array}$ \\
\hline
\end{tabular}

Figure 4 shows a visual representation of the student teachers' responses.

Figure 4. Visual Representation - Headlines

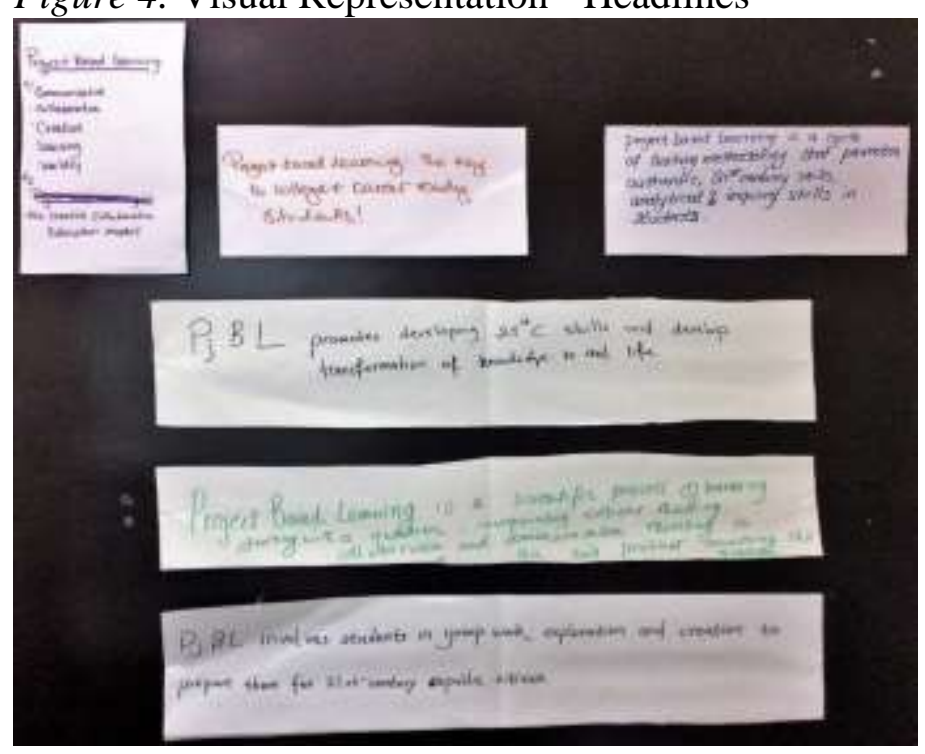




\section{Visual Thinking Routine 5: Color, Symbol, Image}

Instructions: According to Ritchhart, Church, and Morrison (2011), the "Color, Symbol, Image" routine includes the following directions or order:

Think of the big ideas and important themes in what you have just read, seen, or heard.

Choose a color that you think best represents the essence of that idea.

Choose a symbol that you think best represents the essence of that idea.

Choose an image that you think best captures the essence of that idea. (p.119)

Thinking moves: The Color, Symbol, Image routine is used when teachers want their students to think symbolically and figuratively. Students are asked to reflect on the major ideas and assumptions - from a variety of media (audio, video, visuals, text) and represent these ideas and assumptions in nonverbal ways using a color, symbol, or image.

Application: The Color, Symbol, Image routine can be used as frontloading or closure engagements when teachers are looking for interpretation, clarification, and open discussion. Such a routine can be implemented any time during the lesson or unit. Students can be given the choice to work individually, in pairs, or in groups. For assessment purposes, Color, Symbol, Image routine can be used as a pre-assessment, formative assessment, and even as a summative assessment. Table 12 represents a summary of the routine's thinking moves and application.

Classroom Example: Student teachers were considering and exploring gender bias in science. They were asked to read an article that explored gender bias in science. Then, in groups student teachers had to choose a color, symbol, and image that best represented the major ideas in the article. A sharing and discussion session was followed. Table 9 represents a descriptive summary of the student teachers' responses.

Table 9. Student Teachers' Responses - Color, Symbol, Image

\begin{tabular}{|c|c|c|}
\hline Color & Symbol & Image \\
\hline $\begin{array}{l}\text { We chose blue first } \\
\text { because it represents bias } \\
\text { towards boys in science } \\
\text { and we chose pink to } \\
\text { show that we need to } \\
\text { equalize the gender } \\
\text { disparity. }\end{array}$ & $\begin{array}{l}\text { We specifically switched } \\
\text { the colours to show that } \\
\text { we need to move from } \\
\text { gender bias. We are } \\
\text { socialized to think that } \\
\text { blue is for boys and pink } \\
\text { is for girls. }\end{array}$ & $\begin{array}{l}\text { We chose the weighing } \\
\text { scale to represent the need } \\
\text { for gender equality in } \\
\text { science education. }\end{array}$ \\
\hline
\end{tabular}


Figure 5 shows a visual representation of the student teachers' responses.

Figure 5. Visual Representation - Color, Symbol, Image

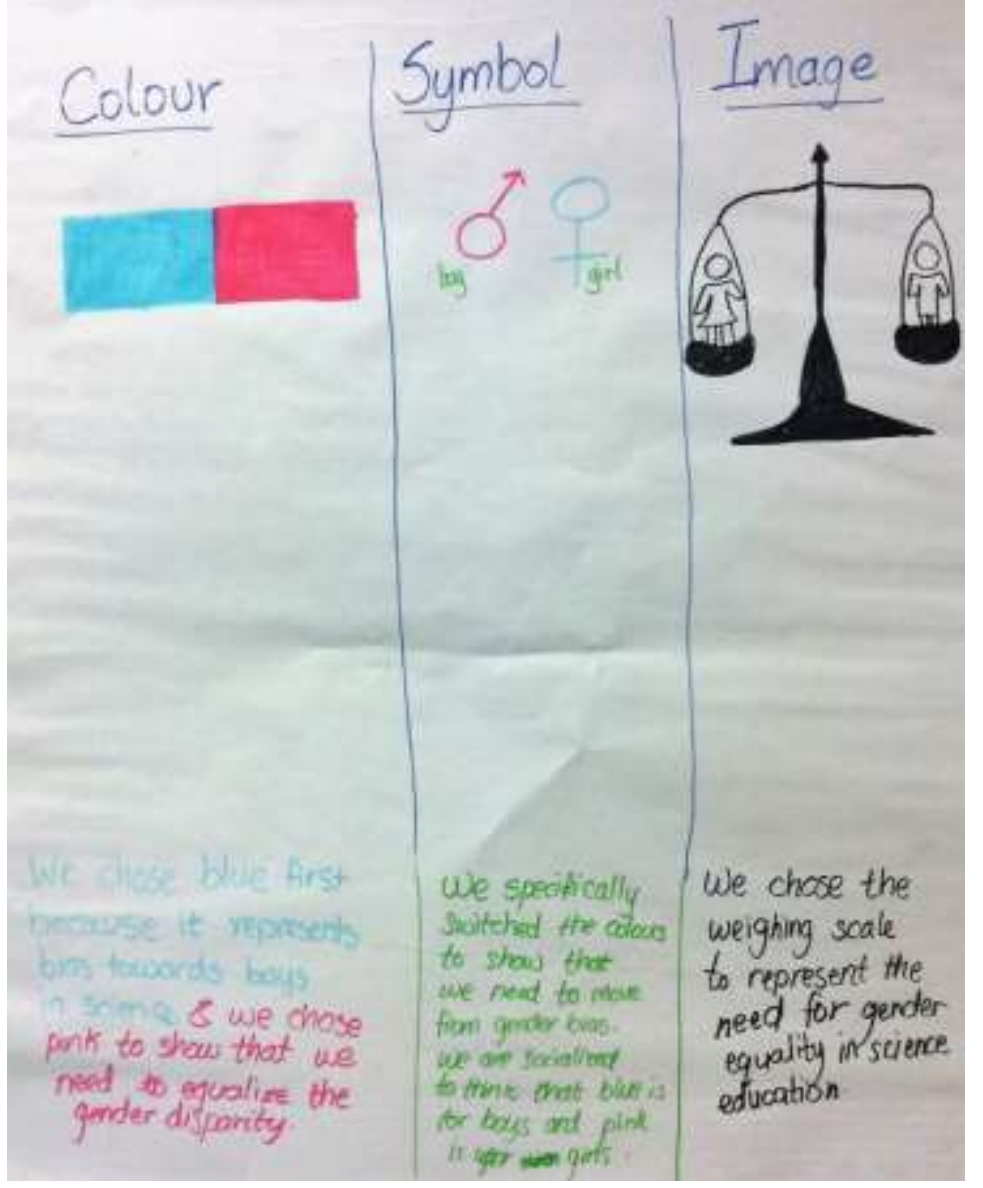

Visual Thinking Routine 6: Sentence-Phrase-Word

Instructions: According to Ritchhart, Church, and Morrison (2011), the "SentencePhrase-Word" routine includes the following directions or order:

In your discussion group, review the text that you have read and each select your own:

Sentence that was meaning to you, that you felt captures a core idea of the text

Phrase that moved, engaged, or provoked you

Words that captured your attention or struck you as powerful (p.207)

Thinking moves: Sentence-Phrase-Word routine is used for summarizing and refining purposes. Such a routine helps students become active readers and derive significant meaning from text with a focus on seizing the core of the text. A discussion of sentence-phrase-word routines allows for the consideration of different meanings, connotations, messages, themes, implications, and inferences. 
Table 10. Student Teachers' Responses - Sentence-Phrase-Word

\begin{tabular}{|c|c|c|}
\hline Words & Phrases & Sentences \\
\hline Systematic & "We're almost done" & $\begin{array}{l}\text { I've learnt how to create a } \\
\text { unit plan from scratch }\end{array}$ \\
\hline Clear & Very motivating & $\begin{array}{l}\text { A quality curriculum } \\
\text { aligns standards, } \\
\text { assessments, and content }\end{array}$ \\
\hline Interesting & $\begin{array}{l}3 \text { Dimensional, Enduring } \\
\text { Understanding, } \\
\text { Assessment vs Evaluation }\end{array}$ & $\begin{array}{l}\text { The course summarizes } \\
\text { the main purpose of } \\
\text { learning and education, } \\
\text { which is conceptual } \\
\text { learning }\end{array}$ \\
\hline Challenging & $\begin{array}{l}\text { Essential questions: Lead, } \\
\text { guide }\end{array}$ & $\begin{array}{l}\text { Curriculum design is a } \\
\text { very essential skill for } \\
\text { effective teaching }\end{array}$ \\
\hline $\begin{array}{l}\text { Instruction, 3D, } \\
\text { Assessment, 2D }\end{array}$ & $\begin{array}{l}\text { Reteaching the } 21^{\text {st }} \\
\text { century thinking }\end{array}$ & $\begin{array}{l}\text { A new and innovative } \\
\text { way to understand } \\
\text { curriculum, instruction, } \\
\text { and assessment }\end{array}$ \\
\hline $\begin{array}{l}\text { Conceptual, KUD, } \\
\text { Questions, Thinking }\end{array}$ & Eye opening & $\begin{array}{c}\text { It explained the process of } \\
\text { Ed. from A to } Z\end{array}$ \\
\hline $\begin{array}{c}\text { Curriculum, Assessment, } \\
\text { Evaluation, } \\
\text { Differentiation }\end{array}$ & $\begin{array}{c}\text { Conceptual } \\
\text { understanding, Backward } \\
\text { design }\end{array}$ & $\begin{array}{c}\text { I was really mixed up } \\
\text { with what is really an } \\
\text { assessment. This course } \\
\text { was encouraging, diff., } \\
\text { beneficial }\end{array}$ \\
\hline $\begin{array}{l}\text { Generalizations, } \\
\text { Performance Tasks }\end{array}$ & $\begin{array}{l}\text { Understanding what a } \\
\text { curriculum is, knowing } \\
\text { difference between } \\
\text { assessment and evaluation }\end{array}$ & $\begin{array}{l}\text { The vision and mission } \\
\text { statements are crucial in } \\
\text { understanding the } \\
\text { experiences (hidden) and } \\
\text { (unhidden) that a student, } \\
\text { teacher, \& parent will } \\
\text { endure }\end{array}$ \\
\hline $\begin{array}{l}\text { Student experiences, } \\
\text { Enduring understanding }\end{array}$ & All encompassing & $\begin{array}{l}\text { I didn't know before what } \\
\text { is really a curriculum, I } \\
\text { didn't know how to } \\
\text { effectively plan my lesson } \\
\text { \& units }\end{array}$ \\
\hline Authentic learning & Thinking outside the box & \\
\hline Guideline map & Provokes thinking! & \\
\hline \multirow[t]{2}{*}{ Interesting } & $\begin{array}{l}\text { Authentic assessments, } \\
\text { KUDS. 2D vs 3D } \\
\text { curriculum }\end{array}$ & \\
\hline & $\begin{array}{l}\text { Authentic learning, } \\
\text { Engaging learning, } \\
\text { Learning styles }\end{array}$ & \\
\hline
\end{tabular}

Application: Sentence-Phrase-Word routine can be administered anytime during the lesson. It is considered a meaningful reflection tool because students have to think of a particular idea, concept, thought, or object and generate a list of 
sentences, phrases, and words that cross their mind. Students can be given the choice to work individually, in pairs, or in groups. For assessment purposes, Sentence, Phrase, Word, routine can be used as a pre-assessment and formative assessment. Table 12 represents a summary of the routine's thinking moves and application.

Classroom Example: Sentence-Phrase-Word was used as an exist ticket in EDCO602: Curriculum, Instruction, and Assessment. During the last session, students were asked to think of the course and reflect on their learning journey by completing a sentence-phrase-word routine. A sharing and discussion session followed. Table 10 represents a descriptive summary of the student teachers' responses.

Figure 6 shows a visual representation of the student teachers' responses.

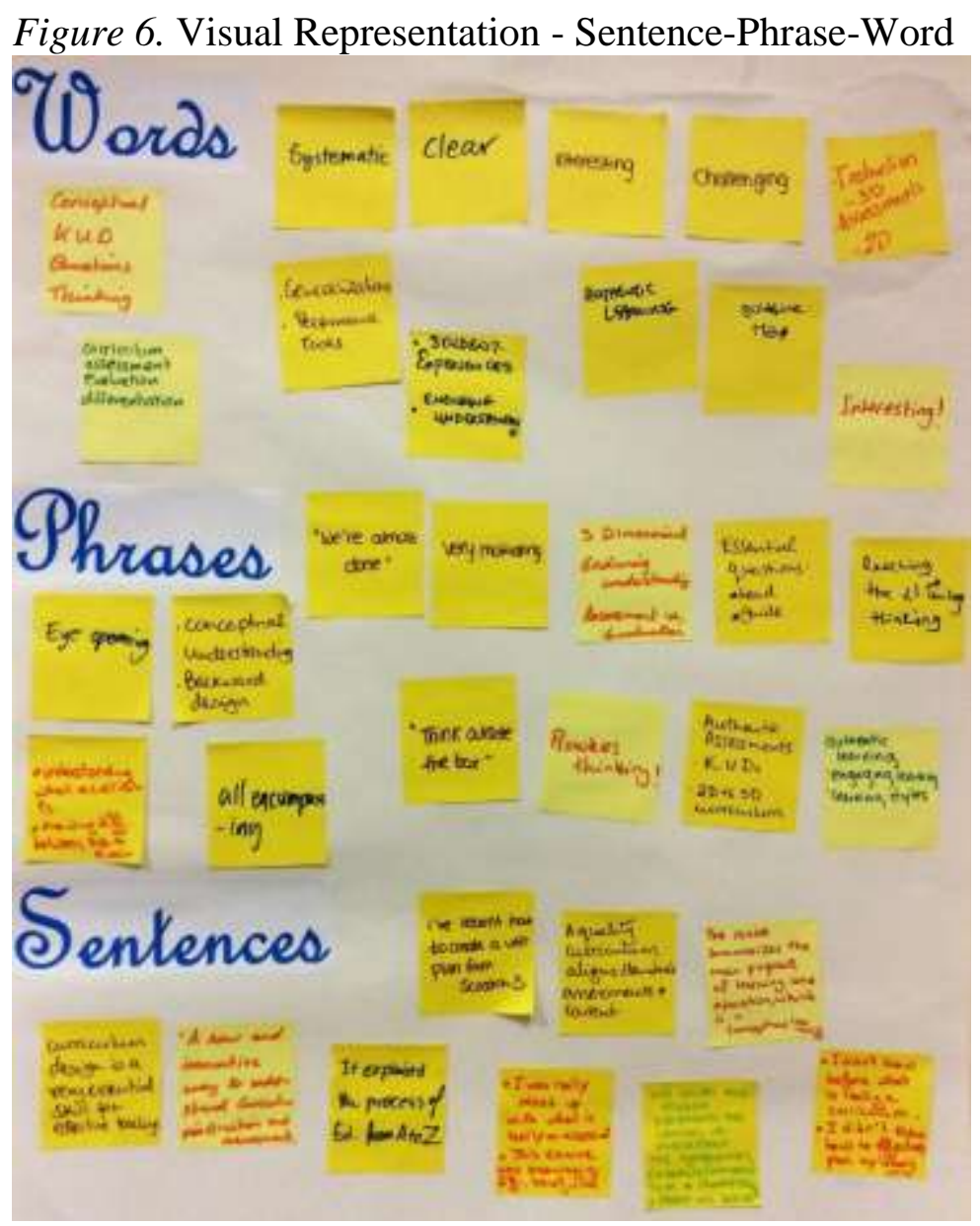

\section{Visual Thinking Routine 7: I used to think.......Now I think}

Instructions: According to Ritchhart, Church, and Morrison (2011), the "I used to think... Now I think ..." routine includes the following directions or order: 
Reflect on your current understanding of this topic, and respond to each of these sentence stems:

I used to think...

Now I think... (p.154)

Thinking moves: I used to think... Now I think routine is an effective routine that allows students to connect on a certain topic or issue and reflect on their acquired knowledge. Students are given the opportunity to explore how their thinking has changed and matured in time. Such a pre/post reflection tool strengthens cognitive abilities and the identification of cause effect relationships as students visually monitor the change in their thinking and identify new opinions and acquired knowledge.

Application: I used to think... Now I think routine can be used when a teacher needs to visually experience the change of students' views, opinions, feelings, ideas, and knowledge as a result of learning. It can be used after a novel learning experience such as reading a piece of literature, watching a movie, listening to a song, or engaging in a classroom debate. Usually, teachers make use of such a routine after completing a unit of inquiry or study. Students can be given the choice to work individually, in pairs, or in groups. For assessment purposes, I used to think... Now I think routine can be used as a formative assessment and even a summative assessment. Table 12 represents a summary of the routine's thinking moves and application.

Classroom Example: During the last portion of the teaching methodology course, student teachers explored what is meant by classroom assessment and inquired into the different tools and methods of assessment. As a closure engagement, student teachers were asked to complete this routine related to the concept of assessment. A sharing and discussion session was followed. Table 11 represents a descriptive summary of the student teachers' responses.

Table 11. Student teachers' responses - I used to think... Now I think

\begin{tabular}{|c|c|}
\hline I used to think that assessment was: & Now, I think that assessment is: \\
\hline Tough and complicated & $\begin{array}{c}\text { I know that assessment is innovative } \\
\text { assessment }\end{array}$ \\
\hline Limited ways to assess & Variety of ways to assess! \\
\hline All about grading & It can be more authentic \\
\hline evaluation & Focus on $21^{\text {st }}$ learning skills \\
\hline Observations and tests only & $\begin{array}{c}\text { Very important to remember your } \\
\text { purpose for assessing }\end{array}$ \\
\hline Assessment is evaluation & $\begin{array}{c}\text { Having students display (show) their } \\
\text { understanding of the concepts }\end{array}$ \\
\hline & Importance of reflection \\
\hline & $\begin{array}{c}\text { Assessment is collecting data while } \\
\text { evaluation is the process of making } \\
\text { judgments }\end{array}$ \\
\hline
\end{tabular}


Table 12. Summary of Visual Thinking Routines

\begin{tabular}{|c|c|c|c|}
\hline $\begin{array}{l}\text { Visual Thinking } \\
\text { Routine }\end{array}$ & $\begin{array}{l}\text { Encourages this } \\
\text { thinking move }\end{array}$ & $\begin{array}{c}\text { Can be used } \\
\text { during this time } \\
\text { of the lesson }\end{array}$ & $\begin{array}{c}\text { Can be used for } \\
\text { the following } \\
\text { assessment } \\
\text { purposes }\end{array}$ \\
\hline $\begin{array}{l}\text { I see, I think, I } \\
\text { wonder }\end{array}$ & $\begin{array}{c}\text { Observing, } \\
\text { interpreting, and } \\
\text { questioning }\end{array}$ & $\begin{array}{c}\text { Frontloading } \\
\text { During } \\
\text { Closure } \\
\end{array}$ & $\begin{array}{l}\text { Pre-assessment } \\
\text { Formative } \\
\text { Summative }\end{array}$ \\
\hline $\begin{array}{l}\text { Connect, Extend, } \\
\text { Challenge }\end{array}$ & $\begin{array}{c}\text { Formulating } \\
\text { connections, } \\
\text { identifying new } \\
\text { knowledge that } \\
\text { pushes the } \\
\text { thinking, } \\
\text { questioning }\end{array}$ & $\begin{array}{c}\text { Frontloading } \\
\text { During } \\
\text { Closure }\end{array}$ & $\begin{array}{l}\text { Pre-assessment } \\
\text { Formative } \\
\text { Summative }\end{array}$ \\
\hline The 4C's & $\begin{array}{l}\text { Formulating } \\
\text { connections, } \\
\text { identifying } \\
\text { concepts and } \\
\text { themes, } \\
\text { questioning, } \\
\text { providing } \\
\text { implications and } \\
\text { changes }\end{array}$ & $\begin{array}{l}\text { During } \\
\text { Closure }\end{array}$ & $\begin{array}{l}\text { Pre-assessment } \\
\text { Formative } \\
\text { Summative }\end{array}$ \\
\hline Headlines & $\begin{array}{c}\text { Summarizing and } \\
\text { outlining }\end{array}$ & $\begin{array}{c}\text { Frontloading } \\
\text { Closure }\end{array}$ & $\begin{array}{l}\text { Pre-assessment } \\
\text { Formative }\end{array}$ \\
\hline $\begin{array}{l}\text { Color, Symbol, } \\
\text { Image }\end{array}$ & $\begin{array}{c}\text { Thinking } \\
\text { symbolically and } \\
\text { figuratively }\end{array}$ & $\begin{array}{l}\text { Frontloading } \\
\text { During } \\
\text { Closure } \\
\end{array}$ & $\begin{array}{l}\text { Pre-assessment } \\
\text { Formative } \\
\text { Summative } \\
\end{array}$ \\
\hline $\begin{array}{l}\text { Sentence, Phrase, } \\
\text { Word }\end{array}$ & $\begin{array}{l}\text { Summarizing and } \\
\text { distilling }\end{array}$ & $\begin{array}{c}\text { Frontloading } \\
\text { During } \\
\text { Closure } \\
\end{array}$ & $\begin{array}{l}\text { Pre-assessment } \\
\text { Formative }\end{array}$ \\
\hline $\begin{array}{l}\text { I used to } \\
\text { think... Now I } \\
\text { think }\end{array}$ & $\begin{array}{l}\text { Reflection and } \\
\text { metacognition }\end{array}$ & $\begin{array}{l}\text { Can be completed } \\
\text { once: As a closure } \\
\text { Can be completed } \\
\text { twice: } \\
\text { As frontloading } \\
\text { and closure }\end{array}$ & $\begin{array}{l}\text { Formative } \\
\text { Summative }\end{array}$ \\
\hline
\end{tabular}

Figure 7 shows a visual representation of the student teachers' responses. 


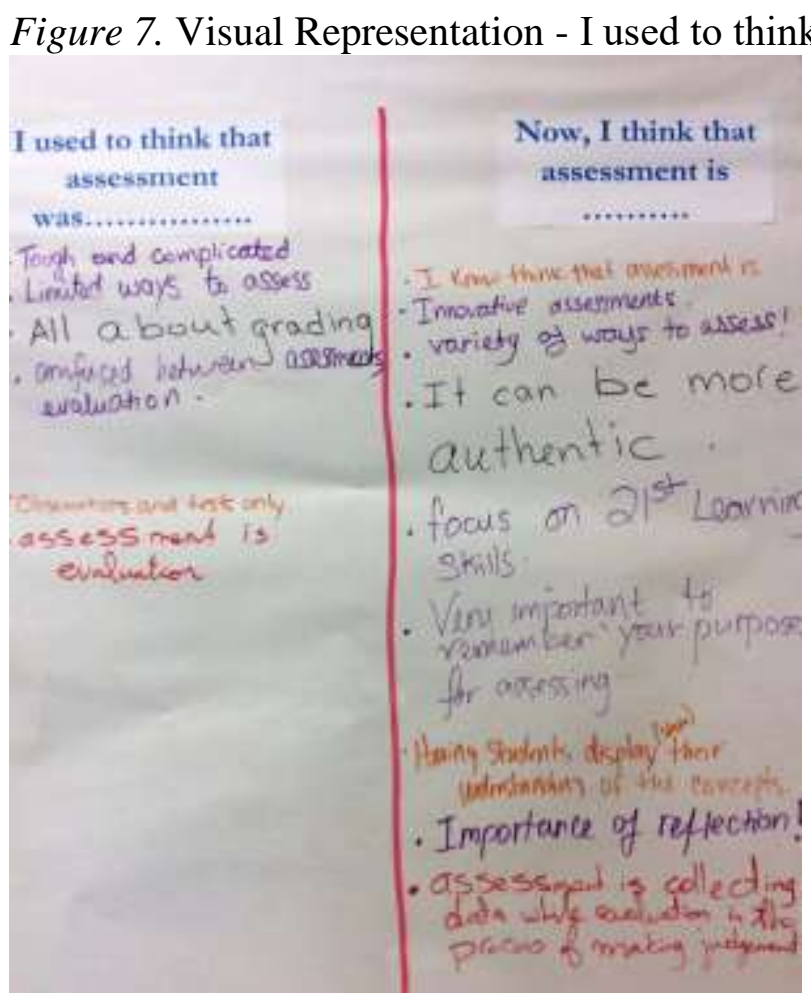

\section{Conclusion}

Any teacher is held accountable for preparing students to contribute to the future world. Learners need to be equipped with skills needed to face problems and create new products and services. No one can deny the fact that thinking skills are essential for dealing with the demands of future life. Students need to connect with previous learning, extend their thinking in new directions, apply their thinking to new situations, identify generalizations, reason with evidence, and formulate meaningful questions. However, it is also important that such skills be armored in a social manner, where students cooperate with one another, take on and complete tasks, listen to one another, discuss ideas, ask questions, and reach decisions. Learning for work and life in our times means helping as many children as possible learn to apply $21^{\text {st }}$ century skills and reach a solid understanding of different core subjects (Trilling \& Fadel, 2009). Implementing visual thinking routines in the classroom will aid teachers and educators in making sure $21^{\text {st }}$ century education is reaching every child. When used in Pre-K - 12 settings, such tools allow for student engagement, collaboration, thinking, curiosity, and creativity.

Given the benefits and importance of including visual thinking routines in daily curricula, how do schools create a thinking culture? What are the essential elements needed to make sure visual thinking routines are effectively and efficiently implemented in schools? First, schools need to believe in a culture of thinking. Therefore, it is central that school administrators and coordinators design curricula that promote student engagement, cooperation, thinking, questioning, 
and $21^{\text {st }}$ century education. Second, teachers should be well-equipped with the knowledge and skills needed to design and implement effective visual thinking routines in the classroom. In order to do so, teachers need to participate in study group programs related to visual thinking routines. Teachers need to have quality time to share and exchange ideas acquired from these study group programs. Third, teachers should be given a trial period to implement visual thinking routines in the classroom and prepare an evaluation of the process: the strengths, the weaknesses, what could be done better, etc. Fourth, trained teachers should offer hands-on training to the ones who are still new and are not familiar with the use of visual thinking routines. Fifth, teachers should participate in ongoing professional development programs related to visual thinking routines. Such programs help teachers stay up to date with the recent trends in visual thinking routines.

Teachers prepare students for the future world. Whether we like it or not, we cannot teach our students the way we did fifteen years ago. Educators need to make sure we equip our students with the skills and knowledge they need to successfully face the outcomes of the $21^{\text {st }}$ century. To do so, students need to be active participants in the learning process. Students, collaboratively, need to observe their surroundings, ask questions, experiment, predict, formulate hypotheses, test hypotheses, arrive at conclusions, communicate their findings, and take action in serving the world. Visual thinking routines in the classroom facilitate these necessary outcomes.

\section{References}

Arends, R. (2014). Learning to Teach. McGraw-Hill Higher Education.

Barahal, S.L. (2008). Thinking about Thinking. Phi Delta Kappan, 90(4), 298-302.

Costa, A. L. (2008). The thought-filled Curriculum. Educational Leadership, 65(5), 20-24.

Dajani, M. (2016). Using Thinking Routines as a Pedagogy for Teaching English as a Second Language in Palestine. Journal of Educational Research and Practice, 6(1), 1-18.

Fleming, S. M. (2014). The Power of Reflection. Scientific American Mind, 25(5), 30-37.

Harvard Project Zero (2010). Research Projects: Visible Thinking. Cambridge, MA: Harvard Graduate School of Education. Retrieved from https://bit.ly/1SaBXb1.

Hattie, J. (2012). Visible Learning for Teachers: Maximizing Impact on Learning. Routledge.

Johnston, P. H. Ivey, G., \& Faulkner, A. (2011). Talking in Class: Remembering what is Important about Classroom Talk. The Reading Teacher, 65(4), 232-237.

McTighe, J., \& Wiggins, G. (2013). Essential Questions: Opening Doors to Student Understanding. ASCD.

Moore, K. D. (2014). Effective Instructional Strategies: From Theory to Practice. Sage Publications.

Orlich, D. C., Harder, R. J., Callahan, R. C., Trevisan, M. S., \& Brown, A. H. (2012). Teaching Strategies: A Guide to Effective Instruction. Cengage Learning.

Rao, M. S. (2010). Soft Skills: Enhacing Employability: Connecting Campus with Corporate. New Delhi, India: IK International. 
Ritchhart, R. (2004). Creative Teaching in the Shadow of the Standards. Independent School, 63(2), 32-40.

Ritchhart, R. (2007). The Seven r's in a Quality Curriculum. Education Quarterly Australia.

Ritchhart, R. (2012). The Power of Questions. Creative Teaching and Learning, 2(4), 8-12.

Ritchhart, R. (2015). Creating Cultures of Thinking: The 8 Forces we must Master to Truly Transform our Schools. John Wiley \& Sons.

Ritchhart, R., Church, M., \& Morrison, K. (2011). Making Thinking Visible: How to Promote Engagement, Understanding, and Independence for all Learners. John Wiley \& Sons.

Ritchhart, R., Palmer, P., Church, M., \& Tishman, S. (2006). Thinking Routines: Establishing Patterns of thinking in the Classroom. Paper presented at the annual meeting of the American Educational Research Association, San Francisco.

Ritchhart, R., \& Perkins, D. (2008). Making Thinking Visible. Educational Leadership, 65(2), 57-61.

Ritchhart, R., Turner, T., \& Hadar, L. (2009). Uncovering Students' Thinking about Thinking using Concept Maps. Metacognition and Learning, 4(2), 145-159.

Salmon, A. K. (2008). Young English Language Learners making Thinking and Language Visible. Colombian Applied Linguistics Journal, 10, 126-141.

Salmon, A. K. (2010). Tools to Enhance Young Children's Thinking. YC Young Children, 65(5), 26-31.

Sousa, D. A. (2011). How the Brain Learns. Corwin Press.

Tishman, S. (2002). Artful reasoning. In Artworks for Schools: A Curriculum for Teaching Thinking in and through the Arts, Grotzer, T., Howich, K., Tishman, S. \& Wise, D. (eds.). Lincoln, MA: DeCordova Museum and Sculpture Park.

Tishman, S., \& Palmer, P. (2005). Visible Thinking. Leadership Compass, 2(4), 1-3.

Tishman, S., \& Palmer, P. (2006). Artful Thinking: Strong Thinking and Learning through the Power of Art. Cambridge, MA: Harvard Graduate School of Education.

Trilling, B., \& Fadel, C. (2009). $21^{\text {st }}$ Century Skills: Learning for Life in our Times. San Francisco, CA: Jossey-Bass.

Visible Thinking. (n. d.). Visible Thinking in Action. Retrieved from https://bit.ly/1Iqg $\mathrm{nZw}$.

Wolberg, R. I., \& Goff, A. (2012). Thinking Routines: Replicating Classroom Practices within Museum Settings. Journal of Museum Education, 37(1), 59-68. 